\section{Rector sacked in Austrian stem-cell scandal}

A fierce academic dispute in Austria reached fresh heights on 21 August when the Medical University of Innsbruck's council dismissed the rector, German immunologist Clemens Sorg, without notice.

In a letter to friends and colleagues in Austria and Germany that was later leaked to the press, Sorg had criticized Austria's academic establishment for its laxness in a case of scientific misconduct at the university's urology department.

Earlier in August, a report by the Austrian Agency for Health and Food Safety found that a clinical trial involving stem cells, run by urologist Hannes Strasser at the university, had serious flaws (see Nature 454, 922-923; 2008). Last week the agency announced that it will hand the report over to public prosecutors.

But the seven-strong university council says that Sorg's "public attacks" against his host country were "unjustified". It accuses Sorg of a "serious breach of duties", including violating official secrecy. In a copy of his letter that appeared in the Austrian daily Tiroler Tageszeitung, Sorg writes that Austria's highest "networks" were attempting hush up what he calls a "medical scandal of unprecedented scale". Sorg says that he intends to sue the Medical University of Innsbruck.

\section{Nuclear group to rule on Indian trade}

The Nuclear Suppliers Group (NSG) will soon decide whether India can trade nuclear fuel and equipment with the group's members. The collaboration met in Vienna last week, and is due to meet again in September.
In the 34 years since its first test, India's nuclear programme has been limited by the nation's refusal to put its name to the nuclear non-proliferation treaty, which all members of the NSG have signed. India wants access to international nuclear trade without restrictions on the growth of its nuclear weapons programme.

A nuclear deal between India and the United States is poised for approval by the US Congress on the condition that the NSG agrees to India's request. Any of the NSG's 45 member countries can veto the application.

\section{NIH promises funds for cheaper DNA sequencing}

The US National Human Genome Research Institute (NHGRI) is ploughing more than $\$ 20$ million into new genetic sequencing technologies.

A series of grants announced on 20 August are the latest step in the institute's drive to bring down the cost of sequencing. The money will support projects such as the development of nanopores. These structures could, it is hoped, identify DNA bases threaded through them from variations in the bases' ionic or electrical properties. The largest grants will go to Daniel Branton and Jene Golovchenko of Harvard University, who are developing this technology, and Mostafa Ronaghi of Illumina in San Diego. Jeffrey Schloss, director of the NHGRI's technology-development programme, says that the institute's goal of a $\$ 1,000$ genome by 2014 "is still realistic".

\section{Inquiry launched into Indian drug trials}

The All India Institute of Medical Sciences (AIIMS) last week launched an inquiry into the deaths of 49 children under 12 years of

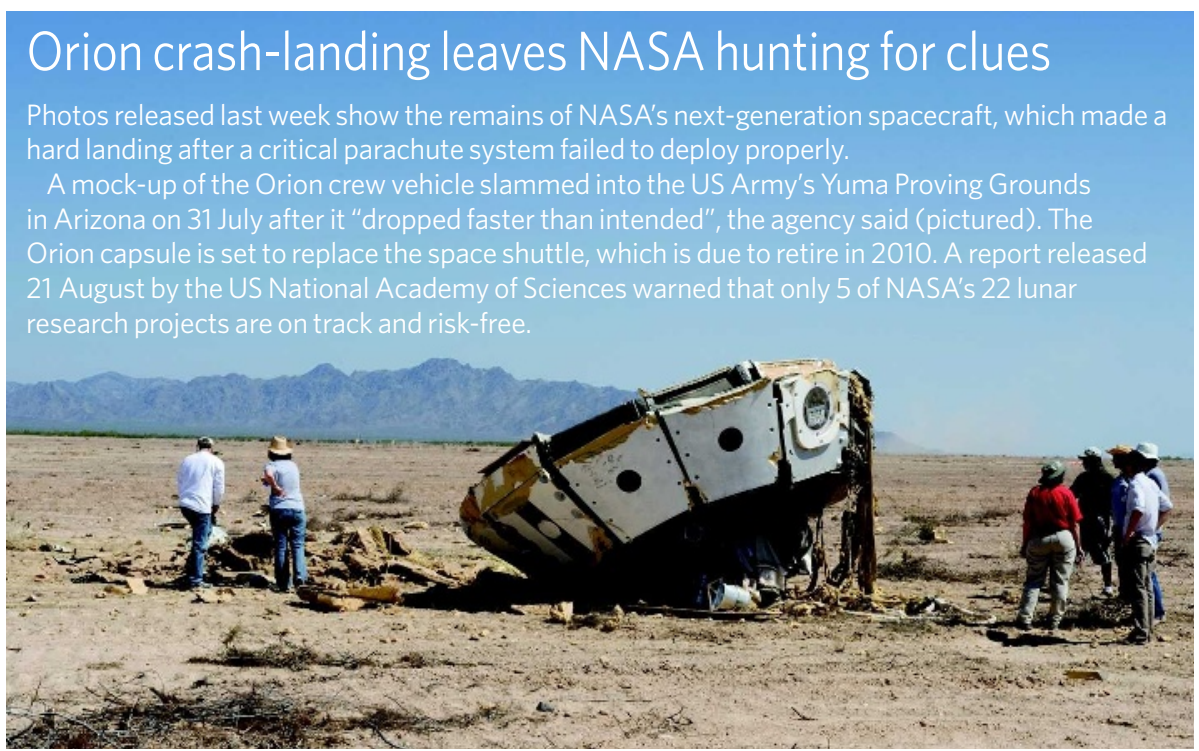

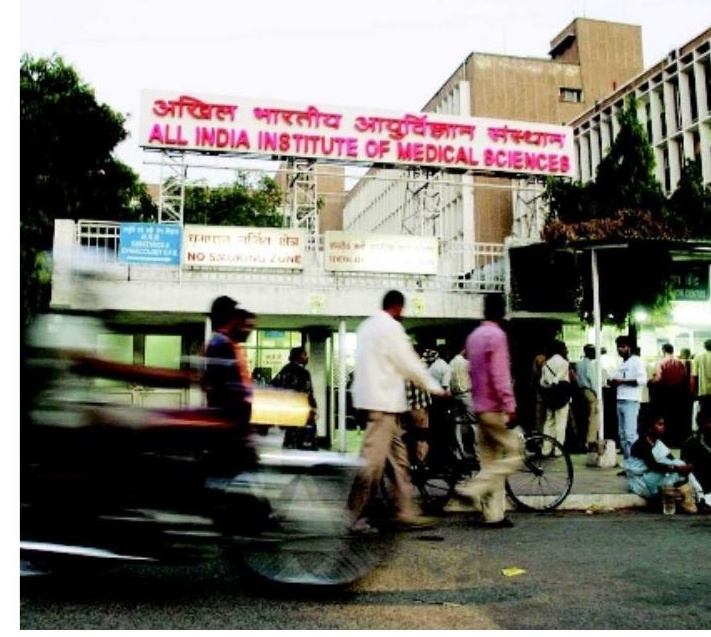

The All India Institute of Medical Sciences is investigating child deaths in several drug trials.

age who have died in drug trials at the New Delhi institution since January 2006. But questions are being raised over whether the inquiry is necessary on scientific grounds.

The death rate in the 42 separate clinical trials was just over $1 \%$. The trials involved a total of 4,142 young patients, 2,728 of whom were under a year old. Among the drugs being tested were the cancer drug rituximab, as well as olmesartan and valsartan, which lower blood pressure.

"The deaths were due to sickness only. All drugs used were of proven safety," Shakti Kumar Gupta, the head of hospital administration at AIIMS, told Nature. The overall mortality rate at the institute, which treats seriously ill patients from all over India, is $3.6 \%$.

\section{Cracks spotted in Greenland's glaciers}

A team at Ohio State University in Columbus has reported a large crack in the longest floating glacier in the Northern Hemisphere. If the crack becomes a break, 160 square kilometres will be lost from the Petermann glacier in northwestern Greenland. This would greatly exceed the glacier's last major ice loss, which saw 86 square kilometres break away in 2000-01.

Glaciologist Jason Box and his colleagues spotted the crack on 3 August. In addition, their daily checks of satellite images of Greenland's glaciers have revealed 29 square kilometres of ice loss from Petermann between 10 and 24 July.

They have also seen 10 square kilometres of ice loss since the end of the last melt season from the Jakobshavn glacier further to the south, which is the world's fastestretreating glacier. 